\title{
Peran Badan Narkotika Nasional Propinsi DIY Dalam Pencegahan Narkoba di Kota Yogyakarta
}

\author{
Rafli Buton \\ Prodi Sosiologi Universitas Widya Mataram \\ E-mail : Rafliude27@gmail.com \\ Djaja Hendra \\ Prodi Sosilogi Universitas Widya Mataram \\ E-mail : Djajahendraaa@gmail.com
}

\begin{abstract}
The issue of drug abuse or drug use is still a problem that is quite concerning for the Indonesian people until now. Indonesia is the right target for drug traffickers because of its large population and a large number of young people. This is a big challenge for the government to overcome this problem, through the institution, namely the National Narcotics Agency. This research was conducted with the aim to finding out what steps have been taken by the National Narcotics Agency to overcoming the problem of drug use, especially in Yogyakarta. This research used descriptive research methods that try to obtain facts and provides an overview of events and phenomena in people's lives to describe what is currently applicable. In overcoming the problem of drug abuse, especially in Yogyakarta, the Yogyakarta Provincial National Narcotics Agency has taken several steps, including increasing knowledge, give understanding and awareness of drug use. Take preventive measures and carry out advocacy. In carrying out its duties, BNNP DIY also always collaborates with other institutions, such as government agencies, private agencies, educational institutions and the community.
\end{abstract}

Keywords : Drug Abuse, BNNP DIY.

\section{Pendahuluan.}

dengan pemberitaan media terkait penyitaan sebanyak 81 karung atau sekitar 1,6 ton sabu yang ditemukan di kapal ikan berisi jaring ketam asal Taiwan yang berhasil disita oleh tim gabungan bea cukai pusat dan mabes polri di perairan batam pada hari Selasa 20 Februari 2018. (Niervana, /25/02/2018). Sungguh tidak bisa di bayangkan kalau sabu sebanyak1,6 ton berhasil masuk dan beredar di Indonesia, ni sangat bahaya dan sangat mengancam masyarakat Indonesia apabila sabu sebanyak itu berhasil diperjualbelikan di Indonesia. Lagi-lagi terungkapnya kasus di atas, telah menambah daftar pengungkapan kasus narkoba yang paling ramai diperbincangkan diseantero media masa yang terjadi dalam kurung waktu Februari 2018. Seperti ramai diberitakan media terkait kasus penyalahgunaan narkoba yang menyeret beberapa artis ibu kota diantaranya Fachri Albar, Roro Fitria, satu artis lainnya yaitu Dhawiya Zaida putri Elvy Sukaesih juga diringkus Direktorat Narkoba Polda Metro Jaya pada hari Jum'at 16 Februari 2018. Dari tangan tersangka polisi berhasil menyita sabu seberat 0,45 grama yang disimpan dalam dompet. (Niervana, 19/02/2018). Tertangkapnya beberapa artis ibu kota dan sabu seberat 1,6 ton dalam kasus narkoba, menunjukkan gawat darurat narkoba kian mejajah Indonesia.

Penyalahgunaan narkoba memang menjadi perilaku serius yang sudah menjangkau semua lapisan masyarakat baik orang tua, remaja maupun anak-anak, sehingga sulit sekali mengontrolnya. Perkotaan dan perkampungan, tempat keramaian dan institusi pendidikan menjadi sasaran para bandar dan pengedar narkoba untuk memasarkan produknya. Dapat dikatakan sulit sekali menemukan satu daerah di Indonesia yang tidak rentan terhadap bahaya narkoba. Sebagaimana Presiden Joko Widodo diawal masa tugasnya menyatakan Indonesia dalam keadaan darurat narkoba. Ancaman narkoba terus membayangi dan menghantui 
kehidupanmasyarakat Indonesia sehingga menyebabkan kekhawatiran yang berkepanjangan.

Kejahatan narkoba merupakan kejahatan internasional, terorganisir dan luar biasa (International Crime), kejahatan yang terkoorganisir (Organize Crime), mempunyai jaringan yang berdampak kepada ketahanan nasional Indonesia (Saputra 2017).Kejahatan ini melibatkan dana yang besar, dukungan teknologi yang canggih dan dampak negatif yang luas baik fisik, psikis, ekonomi, sosial, budaya, , dan lain sebagainya. Jika penyalahgunaan narkoba tidak diantisipasi dengan baik, maka akan merusak dan mengancam keberlangsungan hidup masyarakt Indonesia.Untuk itu, diperlukan kerja sama yang baik dari seluruh komponenbangsa untuk pencegahan penyalahgunaan narkoba (Soedjono, 2000).

Menurut Laporan Kinerja Badan Narkotika Nasional(BNN) tahun 2015, jumlah pengguna narkoba di Indonesia terus bertambah tiap tahun. Dari data laporan terhitung dari tahun 2008, 2011, 2014 dan 2015. Tahun 2008 terdapat 3.362. 527 orang, tahun 2011 terdapat 4.274 .333 orang, tahun 2014 terdapat 4,022.228 orang, tahun 2015 terdapat 4.098 .02 orang dengan rincina pengguna yakni, 70\% dari kalangan pekerja, $22 \%$ dari kalangan mahasiswa dan pelajar, 8\% dari pengangguran. Akibat narkoba 50 orang dinyatakan meninggal setiap hari (18.250 orang pertahun) (Laporan Kinerja BNN 2015).Selain itu penyalahgunaan narkoba telah mengakibatkan nilai kerugian yang tidak sedikit, baik itu kerugian individu dan sosial, maupun biaya ekonomi secara nasional. Kerugian biaya ekonomi penyalahgunaa narkoba pada tahun $2008 \mathrm{Rp}$ 32,4 Trilium, tahun 2011 Rp 48,3 Trilium, tahun 2014 Rp 63,1 Trilium dan tahun 2015 Rp 65,6 Trilium (Laporan kinerja BNN 2015).

Dengan berbagai data dan fakta diatas tidak heran jumlah pemakai narkoba di Indonesia masih tergolong besar dan narkoba sukses masuk ke berbagai kalangan di masyarakat. Narkoba menyentuh berbagai lini kehidupan masyarakat baik kalangan penegak hukum, institusi pendidikan sampai perkampungan padat penduduk.Kondisi terbaru, kepolisian menemukan cara baru pengedar narkoba memasarkan barang haram tersebut. Dengan memanfaatkan jajanan di sekolah, mafia narkoba ingin menyentuh pasar anak-anak sehingga meninggalkan kerisauan mendalam di kalangan orang tua terhadap bahaya peredaran narkoba ini.

Peredaran narkoba yang terus meningkat tentu meninggalkan ancaman yang serius bagi perkembangan masa depan masyarakat, bangsa dan negara. Masa depan generasi muda terancam karena dibayangi dampak penyebaran dan penyalahgunaan narkoba yang terus mencapai tingkatan yang memprihatinkan. (Yashinta: 2013). Penyalahgunaan dan peredaran gelap narkoba merupakan kejahatan luar biasa dan lintas negara yang dapat mengancam dunia. Narkoba menjadi salah satu senjata ampuh dalam proxy war sehingga kekuataan sebuah bangsa dapat dilumpuhkan tanpa harus melalui serangan fisik. Untuk menghadapinya jelas dibutuhkan gerakan penyadaran danpencegahan secara massif dan komperehensif dalam memerangi penyalahgunaan narkoba.

Untuk melaksanakan pencegahan penyalahgunaan narkoba di Indonesia telah dibentuk Badan Narkotika Nasional (BNN). Saat ini, BNN telah memiliki perwakilan daerah di 33 Provinsi, sedangkan di tingkat Kabupaten/Kota BNN telah memiliki 100 BNNK/Kota. Secara bertahap, perwakilan ini akan terus bertambah seiring dengan perkembangan tingkat kerawanan penyalahgunaan narkoba di daerah. Dengan adanya perwakilan BNN di setiap daerah, memberi ruang gerak yang lebih luas dan strategis bagi BNN dalam upaya peningkatan performa pencegahan narkoba, demi terciptanya visi “ Indonesia bebas narkoba”.(http://ww.bnn.go.id).

BNN sebagai organisasi yang menangani penanggulangan narkoba di tanah air, maka BNN dituntut untuk semakin gigih melakukan berbagai upaya strategis untuk 
menggerakan partisipasi seluruh komponen masyarakat, bangsa, dan negara dalam upaya pencegahan narkoba. Salah satu langkah strategis yang dilakukan adalah penguatan kelembagaan BNN sebagaimana diatur dalam Undang-Undang Nomor 35 Tahun 2009 tentang narkotika. Penguatan dimaksud yaitu pembentukan BNNP di tingkat Provinsi dan BNNK/Kota di tingkat Kabupaten/Kota. Langkah strategis ini menjadi langkah penting untuk membantu pencegahan permasalahan narkoba secara serius, karena telah menimbulkan banyak korban jiwa yang kehilangan nyawa akibat terjerat narkoba(http//www.bnn.go.id)

Sebagaimana peran BNN melalui BNN Provinsi (BNNP) dalam upaya pencegahan narkoba salah satunya dengan malakukan tindakan atau aktivitas sosialisasi dan penyuluhan antara lain ke masyarakat, ke sekolah-sekolah yaitu SMP dan SMA serta perguruan tinggi. BNNP juga membentuk satuan tugas di sekolah-sekolah dan perguruan tinggi. BNNPmembuka jalur interaktif dengan masyarakat melalui Radio Republik Indonesia dengan mengundang narasumber antara lain dinas kesehatan, kepolisian resort, jaksa dinas pendidikan, dan lembaga swadaya masyarakat.

Koordinasi dan kerjasama juga dilakukan oleh BNNP dalam pemberantasan peredaran gelap dan penyalahgunaan narkoba salah satunya dengan saling memberikan informasi tentang data terget para pelaku penyalahgunaan narkoba termasuk bersama-sama melakukan kegiatan penyerahan di bawah pengawasan (control delivery), interdiksi pelabuhan, dan interdiksi bandara, razia pada tempat hiburan malam seperti Diskotik, Cafe.

Peran BNN melaui BNNP menjadi tugas besar dari setiap lembaga BNNP yang Merupakan perwakilan dari BNN yang betugas dalam menanggulangi permasalahan narkoba di wilayah provinsi. Salah satu peran BNNP yang menjadi penelitian penulis adalah Badan Narkotika Nasional Provinsi Daerah Istimewa Yogykarata. BNNP DIY sendiri merupakan oraganisasi yang dibentuk pemerintah untuk mengatasi permaslahan narakoba di tingkat provinsi khususnya provinsi DIY. Sebab kasus penyalahgunaan narkoba di DIY terbilang sangat rawan. Sebagaimana hasil penelitian yang dilakukan oleh BNN dan Universitas Indonesia (UI) pada akhir tahun 2016, yang menyatakan bahwa penyalagunaan narkoba di DIY sangat rawan. Menurut data dari Badan Narkotika Nasional Provinsi DIY, jumlah penyalahgunaan narkoba di DIY secara keseluruhan sebanyak tiga puluh ribu (30.000) orang (http//www.bnn.go.id). Data ini menunjukan DIY merupakan salah satu wilayah yang tidak terhindar dari bahaya narkoba. Mengingat Yogyakarta merupakan kota pelajar dan kota wisata. Sebagaimana yang disampaikan eks Ketua BNN Budi Waseso “ Yogyakarta menjadi target utama para mafia narkoba untuk mengahancurkan Indonesia karena Yogyakarta adalah sebagai kota pelajar.

Sebagai daerah yang kini mulai rawan akan penyaahgunaan narkoba. Maka ada dua (2) wilayah di DIY yang menjadi titik potensi kerawaanan penyalahgunaan narkoba yakni Sleman dan Kota Yogyakarta. Berdasarkan data yang penulis kutip dari BNNP DIY penyalahgunaan narkoba berdasarkan pemetaan wilayah, Kota Yogyakarta merupakan wilayah paling rawan kasus penyalahgunaan narkoba DIY. Hal ini dibuktikan dengan salah satu data ungkap kasus penyalahgunaan narkoba di Kota Yogyakartaselama kurung waktu enam (6) tahun mulai dari tahun 2008, 2009, 2010, 2011, 2012, 2013 hingga hingga 2014. Data penyalahgunaan narkoba dimana pada tahun 2008 sebanyak 100kasus dengan jumlah tersangka 114 orang, tahun 2009 sebanyak 89kasus dengan jumlah tersangka 101 orang, tahun 2010 sebanyak 85 kasus dengan jumlah tersangka 93 orang, tahun 2011 sebanyak 58 kasus dengan jumlah tersangka 66 orang, tahun 2012 terdapat 57 kasus dengan jumlah tersangka 69 orang, tahun 2013 terdapat 84 kasus dengan jumlah tersangka 112 orang, dan pada tahun 2014 terdapat 42 kasus dengan jumlah tersangka 71 orang 
(http//www.bnn.go.id). Data di atas menunjukan kota yogyakarta merupakan wilayah yang harus dicegah dari narkoba. Terindikasi 5 Kecamatan yang rawan akan penyalahgunaan narkoba di Kota Yogyakarta yakni : Umbulharjo, Gondokusuman, mergangsang, Gedongtengen dan Tegal rejo.

Untuk mencegah penyalahgunaan narkoba, Badan Narkotika Nasional Provinsi (BNNP) DIY dituntut untuk berperan dalam pencegahan penyalahgunaannarkoba diDIY, khusunya di wilayah Kota Yogyakarta. Dalam hal ini BNNP DIY mempunyai peranan penting dalam melakukan tindakan pencegahan terhadap semua jenis narkoba dan efek yang di timbulkan dari penggunaan narkoba bagi penggunanya. Sebab dibentuknya organisasi BNNP DIY ini untuk mengefektifkan kerja pemerintah dalam memerangi narkoba. Sebagai sebuah organisasi yang ditugaskan untuk berperan melawan narkoba, maka eksistensi Badan Narkotika Nasional Provinsi (BNNP) DIY dituntut untukdapat melakukan perannya dalam mencegah narkoba di DIY. Berdasarkan uraian yang telah diuraikan dalam latar belakang maka peneliti merumuskan ingin mengetahui seperti apa peran Badan Narkotika Nasional Provinsi (BNNP) DIY dalam pencegahan narkoba di Kota Yogyakarta.

\section{Metode.}

Berdasarakan masalah yang akan diteliti dalam penelitian ini, maka metode yang akan digunakan adalah metode penelitian kualitatif. Penelitian ini bersifat penelitian deskriptif analitik yang berusaha mendapatkan fakta serta memberikan gambaran dari suatu peristiwa dan fenomena dalam kehidupan masyarakat.Untuk mendeskripsikan apa-apa yang saat ini berlaku. Di dalamnya terdapat upaya mendeskripsikan, mencatat, analisis, dan menginterpretasikan kondisi yang terjadi di lapangan. Moleong(2001: 23) mengemukakan bahwa metode kualitatif adalah sebagai prosedur penelitian yang menghasilkan data deskriptif berupa kata- kata tertulis atau lisan dari orang-orang dan perilaku yang dapat diamati. Penelitian menggunakan deskriptif analitik dikarenakan peniliti ingin mengetahui gamabaran ilimiah tentang peran BNNP DIY dalam pencegahan narkoba di Kota Yogyakarta.

\section{Hasil dan Pembahsan.}

Peran secara teori merupakan anggapan bahwa orang dalam hidup bermasyarakat senantiasa berusaha melakukan peran seperti dikehendaki oleh orang lain. Dengan demikian, identitas seseorang adalah dibentuk dalam rangka memberi respon dari perlakuan dan harapan orang lain. Dengan kata lain, tindakan seseorang lahir sebagai produk dari bagaimana orang lain memperlakukan dirinya, sekaligus dari keinginannya sendiri sebagaimana supaya dapat diterima oleh orang lain.

Peran tidaklah sekedar kesempatan melakukan tindakan, tetapi lebih daripada itu adalah cara bagaimana kontak dan komunikasi seharusnya dilakukan. Peran memungkinkan orang membangun pola bertingkahlaku dan bersikap, dan didalam didalam peran terendap pula strategi bagaimana seharusnya menguasai berbagai macam situasi(Usman 2012: 59-60) Dalam peran bila individu-individu menempati kedudukan-kedudukan tertentu, maka mereka merasa bahwa setiap kedudukan yang mereka tempati itu menimbulkan harapan-harapan (expectation) tertentu dari orang-orang disekitarnya.Dalam peran yang berhubungan dengan pekerjaannya, seseorang diharapkan menjalangkan kewajiban-kewajibannya yang berhubungan dengan peran yang dipegannya. Oleh karena itu Gross, Maso dan McEachern (1958; 2729), mendefinisikan peran sebagai seperangkat harapan-harapan yang dikenakan pada individu yang menempati kedudukan sosial tertentu. Harapan-harapan tersebut merupakan pertimbangan dari norma-norma sosial dan oleh karena itu dapat dikatakan bahwa peranan-peranan itu ditentukan oleh norma-norma di dalam 
masyarakat, maksudnya: kita diwajibkan melakukan hal-hal yang diharapkan oleh "masyarakat" di dalam pekerjaan kita, di dalam keluarga dan di dalam perananperanan lainnya. Kadang-kadang para ahli sosiologi menggambarkan peranan-peranan dalam arti: apa yang diharapkan dan dituntut masyarakat. Di dalam peranan terdapat 2 (dua) macam harapan, yaitu : 1). Harapanharapan dari masyarakat terhadap pemegang peran atau kewajiban-kewajiban dari pemegang peran, dan 2). Harapan-harapan yang dimiliki oleh si pemegang peran terhadap 'masyarakat” tau terhadap orangorang yang berhubungan dengannya dalam menjalangkan peranannya atau kewajibannya.

Pemikirian tentang peranan sebagai seperangkat harapan yang ditentukan oleh masyarakat terhadap pemegang-pemegang kedudukan sosial adalah sejalan dengan perspektif masyarakat. Perspektif ini berpendapat bahwa tiap individu memegang peran yang diberikan oleh masyarakat kepada mereka. Dalam pandangan ini, peranan-peranan dapat dilihat sebagai bagian dari struktur masyarakat,misalnya peranan-peranan dalam dalam pekerjaan, keluarga, kekuasaan dan peranan-peranan lain, yang diciptakan oleh "masyarakat bagi manusia.

Setiap individu, komunitas , kelompok maupun organisasi tidak terlepas dari peran yang dimiliki, dan peran yang tidak dapat dipisahkan dari masyarakat adalah peran organisasi. Menurut Max Weber (1947) organisasi secara pengertian merupakan suatu bentuk sosial yang dihasilkan oleh ikatan antarpersonal yang memiliki aturan untuk membatasi dan menata berbagai fungsi yang bersifat reguler, menata tindakan individual dan relasi sosial, dan relasi yang terbentuk itu mempunyai seseorang kepala dan staf. Sedangkan secara perspektif teori, pokok pikiran utama Max Weber yang berkaitan dengan organisasi adalah birokrasi. Weber mengemukakan, pertumbuhan suatu organisasi berskala besar dan yang diprediksi secara pasti hanya akan terjadi apabila pertumbuhan itu disertai formalisasi. Lebih lanjut, menurut Weber, hanya organisasi menggunakan prinsip-prinsip birokrasi akan dapat menampilkan pekerjaan lebih efisien dan mencapai hasil maksimum, dan semuanya itu dilakukan melalui apa yang kata Max Weber disebut sebagai wewenang.

Wewenang merupakan kombinasi dari kekuasaan dan legitimasi, meskipun kita dapat memandang kekuasaan sebagai legitimasi pula (Etzioni, 1964). Ada tiga tipe wewenang, menurut Max Weber, yaitu

a. Wewenang rasional/legal (ration/legal ground) yakni wewenang yang dimiliki oleh seseorang dalam organisasi untuk melaksanakan komando atau memberikan perintah dari relasi yang impersonal kepada orang lain, berdasarkan aturan-aturan normatif yang jelas, benar dan adil. Wewenang legal rasional merupakan wewenang yang sangat relevan dengan konsep birokrasi. Wewenang dalam suatu birokrasi bersumber dari kekuasaan birokrat, kekuasaan tersebut bersumber dari peraturan-peraturan birokrasi atau aturan peraturan yang dibuat oleh para birokrat untuk memerintah dan perintah itu akan diterima oleh para anggota organisasi. Weber mengemukakan beberapa prinsip birokrasi, yakni birokrasi itu berbasis pada peraturan, seperti aturan untuk memcahkan masalah, menetapkan standarisasi, dan menjaga kesetaraan dalam organisasi; birokrasi itu berbasis pada konsep kompetensi. Jadi dalam birokrasi harus ada pembagian kerja secara sistematis di mana setiap peran harus dirumuskan secara jelas hak dan kekuasaan dari peran tersebut, esensi dari birokrasi adalah hierarki, para anggota organisasi yang ditunjuk untuk melaksanakan peran tersebut harus berdasarkan pada pengetahuan dan pelatihan.

b. Wewenang tradisonal (traditional ground), yakni satu wewenang yang dimiliki oleh seseorang yang memiliki status tertentu dalam organisasi sehingga 
dia dapat memerintah dan membangun kekuatan dan loyalitas orang lain terhadap dia. Penerimaan dan pengakuan terhadap tradisi wewenang ini juga merupakan salah satu bentuk tradisi legitimasi.

c. Wewenang kharismatik (charismatic ground), yakni wewenang yang dimiliki oleh seseorang yang mempunyai kharisma, dari karisma itulah dia mempunyai kekuasaan dan kewibawaan untuk memerintah orang lain sehingga mereka akan menaati perintah itu dan merasa terikat dengan pola-pola normatif dan bahkan merasa diselamtkan oleh yang memiliki kharismatik.

Berdasarkan perspektif Max Weber di atas, bahwa organisasi memiliki wewenang untuk mengatur segala keprluan atau kebutuhan organisasi. Maka dalam hal ini Badan Narkotika Nasional Propinsi (BNNP) khusunya BNNP DIY sebagai organisasi yang berperan dalam menangani permasalahan narkoba pun tidak luput dari yang namanya wewenang. Artinya BNNP DIY merupakan sebuah organisasi yang memiliki wewenang untuk mengatur segalah kebutuhan seperti; mengatur tindakan dalam mencegah masalah narkoba, mengatur program kegiatan mencegah masalah narkoba, mengatur kegiatan membangun jaringan kerja sama dalam mencegah narkoba dan mengatur wewenang yang dilakukan oleh BNP DIY untuk mencegah narkoba. Dari wewenangwewenang tersebut dapat digunakan BNNP DIY untuk menjalangkan salah satu tugas besarnya yakni melakukan pencegahan terhadap narkoba.

Pencegahan secara etimologi berasal dari bahasa latinpravenire yang artinyasebelum/antisipasi/mencegah untuk tidak terjadi sesuatu. Dalam pengertian yang luas preventif diartikan sebagai upaya secara sengaja dilakukan untuk mencegah terjadinyan gangguan, kerusakan, atau kerugian bagi seseorang (Oktavia 15/05 2013). Maka pencegahan terhadap narkoba yang dilakukan BNNP DIY merupakan salah satu tugas besar untuk bertindak dalam meningkatkan pengetahuan, pemahaman, dan kesadaran tentang narkoba. Tindakan mencegah faktor-faktor penyebab penyalahgunaan narkoba serta melibatkan instansi penegak hukum, organisasi masyarakat, lembaga pendidikan untuk bekerja sama dalam melakukan tindakan pencegahan terhadap narkoba. Sebagaimana peran BNNP DIY terhadap pencegahan narkoba di Kota Yogyakarta sebagai berikut:

\section{Peran Badan Narkotika Nasional Provinsi DIY}

Badan Narkotika Nasional yang secara khusus diberi kewenangan oleh Undang-Undang Narkotika nomor 35 Tahun 2009 dalam Pasal 70 huruf b, BNN mempunyai tugas untuk melakukan pencegahan dan memberantas penyalahgunaan dan peredaran gelap Narkotika dan Prekursor Narkotika yang dalam hal ini dapat dilakukan langsung oleh Badan Narkotika Nasional di tingkat Pusat maupun dapat di amanatkan kepada lembaga di bawahnya yaitu Badan Narkotika Nasional Provinsi maupun Badan Narkotika Nasional di tingkat Kabupatan/Kota.

Dalam upaya untuk melakukan pencegahan terhadap narkoba di Kota Yogaykarta, Badan Narkotika Nasional Provinsi (BNNP) DIY mempunyai peran prioritas untuk memerangi narkoba baik ditingkat DIY maupun tingkat Kabupaten kota, khususnya Kabupaten Kota Yogayakarta. Berikut ini penulis akan menjelaskan peran dari Badan Narkotika Nasional Provinsi (BNNP) DIY dalam melakukan pencegahan terhadap narkoba :

\section{1.a.Tindakan Preventif Yang Dilakukan Oleh BNNP DIY Dalam Upaya Pencegahan Narkoba}

Tindakan pencegahan adalah tindakan yang dilakukan untuk mencegah atau menjaga kemungkinan akan terjadinnya kejahatan. Menurut A. Qirom Samsudin M, dalam kaitannya untuk melakukan tindakan preventif adalah mencegah akan terjadinya 
kejahatan itu lebih baik daripada mendidik seseorang penjahat menjadi baik kembali, sebab bukan saja diperhitungkan segi biaya, usaha ini lebih mudah dan akan mendapat hasil yang memuaskan atau mencapai tujuan demi terwujudnya ketentraman di masyarakat.

Tindakan pencegahan dalam hal pencegahan narkoba ini dilakukan oleh Bidang Pencegahan. Bidang ini mempunyai tugas, yaitu melaksanakan kebijakan Pencegahan, Pemberantasan, Penyalahgunaan dan Peredaran Gelap Narkotika (P4GN).

Badan Narkotika Nasional Propvinsi (BNNP) DIY dalam upaya tindakan pencegahan narkoba di Kota Yogyakarta telah diatur oleh Badan Narkotika Nasioanal (BNN). Jadi program pencegahan narkoba telah ditentukan oleh BNN. Maka dari itu tugas dari Badan Narkotika Nasional Provinsi (BNNP) DIY adalah menjalankan program pencegahan yang sudah ditentukan. Selain itu jawaban yang disampaikan oleh informan diatas, menunjukkan bahwa pencegahan merupakan salah satu progaram penting dari BNNP DIY untuk memproteksi masyarakat Kota Yogyakarta dari bahaya narkoba.

Tindakan preventif dalam hal pencegahan narkoba dilakukan oleh Bidang Pencegahan . Bidang ini mempunyai tugas, yaitu melaksanakan kebijakan teknis Pencegahan,

Pemberantasan Penyalahgunaan dan Peredaran Gelap Narkotika (P4GN) di bidang Provinsi. Dalam melaksanakan tugasnya tersebut, fungsi bidang pencegahan sebagaimana tertuang dalam Pasal 11 Peraturan Kepala Badang Narkotika Nasional Republik Indonesia Nomor 7 Tahun 2016 tentang Perubahan Ketiga Atas Peraturan Kepala Badan Narkotika Nasional Nomor 3 Tahun 2015 tentang Organisasi dan tata Kerja Badan Narkotika Nasional Provinsi dan Badan Narkotika Nasional Kabupaten/Kota, yaitu:

a. Penyiapan pelakasanaan koordinasi penyusunan rencana strategis, dan rencana kerja tahunan P4GN di bidang pencegahan dan pemberdayaan masyarakat dalam wilaya Provinsi.

b. Penyiapan pelaksanaan diseminasi informasi dan advokasi P4GN di bidang pencegahan dalam wilayah Provinsi;

c. Penyiapan pelaksanaan peran serta masyarakat dan pemberdayaan alternatif P4GN di bidang pemberdayaan masyarakat dalam wilayah Provinsi;

d. Penyiapan pelaksanaan pembinaan teknis dan supervisi P4GN di bidang pencegahan dan pemberdayaan masyarakat kepada BNNK/Kota dalam wilayah Provinsi; dan

e. Penyiapan pelaksanaan evaluasi dan pelaporan P4GN di bidang pencegahan dan pemberdayaan masyarakat dalam wilayah Provinsi.

Berdasarkan hasil studi dokumentasi dan hasil wawancara dengan informan dapat menunjukkan bahwa tugas dan wewenang Badan Narkotika Nasional Provinsi (BNNP) DIY terkait dengan pencagahan narkoba, BNN telah membuat Undang-Undang Narkotika Pasal 11 Peraturan Kepala Badang Narkotika Nasional Republik Indonesia Nomor 7 Tahun 2016 tentang Perubahan Ketiga Atas Peraturan Kepala Badan Narkotika Nasional Nomor 3 Tahun 2015 tentang Organisasi dan tata Kerja Badan Narkotika Nasional Provinsi dan Badan Narkotika Nasional Kabupaten/Kota.

Kebaradaan regulasi akan menjadi realisasi dari peran BNNP DIY, untuk mematuhi, mengatur, menjalangkan aturan yang telah disahkan, terutama terkait dengan regulasi mengenai pencegahan narkoba.

\section{1.a.1.Diseminasi Informasi}

Dissemination/Diseminasi

adalah merupakan program kegiatan pencegahan narkoba yang ditujukan kepada suatu kelompok target atau kelompok pelajar, pekerja maupun masyarakat umum supaya mereka memperoleh informasi, menimbulkan kesadaran dalam diri, menerima dan pada akhirnya diharapakan dapat memanfaatkan informasi-informasi tentang bahaya narkoba.. 
Diseminasi informasi ini tujuan memberikan pemahaman kepada masyarakat tentang narkoba dan dampak buruknya. Pada kegiatan desiminasi informasi ini kita dari BNNP DIY akan mensosialisasikan hal-hal yang berhubungan dengan jenis-jenis narkoba. Kemudian juga mensosialisasikan hukuman bagi pengedar narkoba. sehingga pengguna jadi mikir untuk tidak menyalahgunakan narkoba. (SY)

Menurut peneliti program diseminansi informasi merupakan program pencegahan narkoba yang sangat bagus untuk mencegah narkoba. Karena Pada program ini, yang dilakukan oleh BNNP DIY adalah menyebarluaskkan informasi-informasi atau pengetahuan mengenai bahaya narkoba. Dengan begitu, program ini akan memberikan pengetahuan, pemahaman, dan kesadaran masyarakat Kota Yogyakarta akan bahaya penyalahgunaan narkoba.

\section{1.a.2.Melakukan Advokasi}

Kegiatan advokasi adalah kegiatan yang bertujuan untuk mengajak peran serta permerintah, swasta, dan masyarakat untuk bersama-sama melakukan pencegahan terhadap narkoba. Keterlibatan seluruh komponen masyarakat dengan BNNP DIY, bertujuan untuk melakukan upaya perventif terhadap narkoba. Pada kegiatan advokasi ini BNNP Provinsi DIY mengajak pemerintah, maupun swasta untuk membantu mencegah narkoba misalnya, dengan membuat regulasi mencegah narkoba, ataupun membentuk relawan anti narkoba.

'Tugas dari program advokasi ini adalah kita mengajak keterlibatan pemerintah maupun swasta untuk ikut melakukan pencegahan terhadap narkoba.Keterlibatan pemerintah dan swasta adalah kita mengajak mereka untuk membantu BNNP DIY dalam melakukan upaya pencegahan narkoba, terutama untuk lingkungannya sendiri maupun di luar lingkungannya. Misalnya, dengan membuat regulasi anti narkoba atau membentuk relawan anti narkoba"(BW)

Program advokasi ini menurut peneliti merupakan salah satu program kerja yang tidak kalah penting dengan program desiminasi informasi. Karena pada program ini, yang dilakukan oleh BNNP DIY adalah mengajak pimpinan-pimpinan instansi pemerintah atau swasta untuk berafiliasi dalam melakukan pencegahan terhadap narkoba di Kota Yogyakarta.

\section{Melakukan Koordinasi Dan Kerjasama Dengan Lembaga Terkait.}

Selain menjalankan program kegiatan diseminasi informasi dan advokasi sebagai bentuk peran terhadap uapaya pencegahan narkoba, Badan Narkotika Nasional Provinsi (BNNP) DIY juga melakukan melakukan koordinasi dan kerjasama dengan lembaga-lembaga terkait. Dalam hal ini pihak BNNP DIY dapat berkoordinasi dengan kepolisian, instansi pemerintah dengan bergabungnya penyidik BNN dengan penyidik-penyidik baik dari penyidik polisi maupun penyidik PNS. Karena dengan adanya koordinasi dan kerjasama antara lembaga penegak hukum dan lembaga pemerintah maka hal tersebut tentu akan dapat membantu mengoptimalisasikan peran Badan Narkotika Nasional Provinsi (BNNP) DIY dalam upaya melakukan pencegahan narkoba di Kota Yogyakarta.

"Ya untuk kerjasama dan koordinasi Badan Narkotika Nasioanl Provinsi (BNNP) DIY turut melibatkan lemabaga kopolisian dan pemerintah untuk dapat bekerjasama dalam upaya melakukan pencegahan terhadap narkoba"(SY)

\section{Pencegahan Narkoba}

Sesuai dengan Peraturan Kepala Badan Narkotika Nasinal Nomor 04 Tahun 2010 tentang Organisasi dan Tata Kerja Badan Narkotika Nasional Provinsi dan Badan Narkotika Nasional Kabupaten/Kota sebagaimana telah diubah Peraturan Kepala Badan Narkotika Nasional Nomor 04 Tahun 2013, Bidang Pencegahan mempunyai tugas melaksanakan kebijakan teknis P4GN di bidang Pencegahan dalam wilayah Provinsi

Bidang pencegahan Badan Narkotika Nasional Provinsi (BNNP) DIY secara umum menyelenggarakan tugas guna 
pencapaian sasaran strategis dalam rangka meningkatkan daya tangkal (imunitas) masyarakat terhadapa bahaya penyalahgunaan narkotika anatara lain:

1. Meningkatkan pengetahuna, pemahaman, dan kesadaran pelajar, mahasiswa, pekerja, keluarga, dan masyarakat khususnya yang rentang/beresiko tinggi terhadap bahaya penyalahgunaan dan peredaran gelap narkoba.

2. Meningkatkan peranan instansi pemerintah dan kelompok masyarakat dalam upaya menciptakan dan meningkatkan pengetahuan, pemahaman, dan kesadaran masyarakat di lingkungan masing-masing terhadap bahaya penyalahgunaan dan peredaran gelap narkotika

3. Meningkatnya pelajar, mahasiswa dan pekerja sebagai kader anti narkoba yang memiliki ketrampilan menolak penyalahgunaan dan peredaran gelap narkotika.

\section{3.a.Meningkatkan Pengetahuan Dan Pemahaman Narkoba}

Meningkatkan pengetahuan dan pemahaman narkoba merupakan tidakan pencegahan narkoba yang dilakukan oleh BNNP DIY melalui bidang pencegahan sehingga masyarakat jadi tahu dan paham akan bahaya menyalahgunakan narkoba. Sebab tujuan utama dari didirikannya BNNP DIY adalah menanggulangi penyalahgunaakan narkoba, sehingga tindakan meningkatkan pengatuhan dan pemahaman narkoba dapat mengatasi atau mengurangi penyalahgunaan narkoba.

"Meningkatkan pengetahuan dan pemahaman narkoba merupakan kegiatan yang sangat membantu masyarakat untuk mendapat informasi-informasi seputar P4GN. Bidang pencegahan mimiliki beberapa metode untuk meningkatkan pengetahuan dan pemahaman narkoba misalnya, melakukan sosialisasi, bentuknya bisa FGD, pentas seni, maupun pameran,. Selama kami melakukan sosialasi ke masyarakat, disambut baik oleh masyarakat serta berbagai komentar dukungan terhadap kegiatan yang kami jalankanan, meskipun ada bebearapa masukan dari masyarakat kami pun terima. Tapi secera keseluruhan kegiatan meningkatkan pengetahuan dan pemahaman narkoba sudah kita lakukan ke masyarakat.Banyak masyarakat yang bergabung bersama kami sebagai perpanjangan tangan kami untuk melakukan sosialisasi narkoba di lingkungan mereka masing-masing.(SY).

BNNP DIY memiliki berbagai cara untuk meningakatkan pengetahuan dan pemahaman akan bahaya narkoba, mulai dari melakukan sosialisasi, bentuknya bisa FGD, pentas seni, dan pameran. Semua cara tersebut menjadi kegiatan BNNP DIY untuk melakukan pencegahan terhadap narkoba. Meningkatkan pengetahuan dan pemahaman akan bahaya narkoba sangat penting untuk dilakukan. Sebab pengetahuan dan pemahaman akan bahaya narkoba sangat berpotensi mencegah seseorang menyalahgunakan narkoba.

Meningkatkan pengetahuan dan pemahaman kepada masyarakat tentang bahaya narkoba, itu akan membantu masyarakat untuk memperoleh pengetahuan dan pemahaman tentang bahaya narkoba. Sehingga masyarakat itu menjadi tahu bahwa narkoba itu berbahaya, dan masyarakat pun tersadarkan untuk mencegah diri dari bahaya narkoba.

\section{3.b.Mencegah Faktor Penyalahgunaan Narkoba}

Pencegahan narkoba yang dilakukan oleh BNNP DIY dengan upaya meningkatkan pengetahuan dan pemahaman narkoba dapat mencegah faktor- faktor yang menyebabkan seseorang menyalahgunakan narkoba.

Orang yang menggunakan narkoba karena pengetahuan dan pemahaman narkoba lemah. Sehingga tugas kita adalah mensosialisasikan pengetahuan tentang narkoba. Untuk mencegahan faktorfaktor penyalahgunaan narkoba maka yang kita lakukan adalah kita memberikan pengetahuan dan pemahaman tentang narkoba. (SY)

Faktor-fakror penyebab seseorang menyalahgunakan narkoba di karenakan lemahnya pengetahuan dan pemahaman akan 
bahaya narkoba. Ada beberapa faktor penyebab seseorang menyalahgunakan narkoba misalnya, individu atau pergaulan. Dua faktor ini dapat dicegah dengan cara mengajarkan pengetahuan dan pemahaman kepada masyarakat tetang narkoba. Untuk itu penting sekali pengetahuan dan pemahaman narkoba perlu untuk disosialisasikan ke individu atau masyarkat. Sehingga fakatorfaktor penyebab penyalahgunaan narkoba dapat dicegah.

\section{Meningkatkan Peran Instansi Pemerintah Dan Masyarakat}

BNNP DIY sebagai lembaga yang memiliki peran sentral dalam melakukan pencegahan terhadap penyalahgunaan narkoba, turut melibatkan peran serta instansi pemerinta, swasta, lembaga pendidikan untuk berperan dalam mensosialisasikan pengetahuan dan pemahamn tentang narkoba dan bahayanya di lingkungan masing-masing .

Karena kita kan kerjanya melibatkan instansi lain. Banyak sekali yang dilibatkan seperti lembaga pendidikan, institusi pemerintah, instansi swasta; perusahaan, LSM, ormas, seluruh komponen masyarakat.(SY).

Keterlibataan seluruh komponen masyarakat sendiri tidak terlepas dari kerja kolektif antara instansi pemerintah, swasta maupun masyarakat dengan BNNP DIY untuk melakukan pencegahan narkoba. Bidang pencegahan mempunyai 4 (empa) segmen yang menjadi sasaran yaitu lingkungan pendidikan, masyarakat, pemerintah, dan swasta/ pekerja. Dalam menyasar segmen lingkungan pendidikan, masyarakat, swasta maupun pekerja, bidang pencegahan Badan Narkotika Nasional Provinsi Daerah Istimewa Yogyakarta mempunyai 2 (dua) program dalam meningkatkan pengetahuan dan pemahaman narkoba yakni ; Diseminasi Informasi dan Advokasi.

\section{4.a.Sosialisasi Pencegahan Narkoba Terhadap Pelajar Dan Mahasiswa}

Diseminasi informasi pencegahan narkoba melalui sosialisasi kepada pelajar dan mahasiswa adalah untuk menyebarluaskan narkoba dan bahayanya sehingga pelajar dan mahasiswa dapat memiliki pengetahuan dan pemahaman tentang narkoba dan bahayanya. Hal ini dilakukan agar pelajar dan mahasiswa imun untuk tidak menyalahgunakan narkoba..

"Sosialisasi diseminasi informasi ke kalangan pelajar dan mahasiswa adalah untuk meningkatkan pengetahuan dan pemahaman narkoba dan bahayanya agar pelajar dan mahasiswa itu imun untuk tidak menggunakan narkoba. Alhamdulillah kegiatan yang kita lakukan dengan menyasar pelajar dan mahasiwa responnya sangat positif. Sudah banyak pelajar dan mahasiswa bergabung bersama BNNP DIY dengan membentuk kader penyuluh anti narkoba.'(SY)

Berdasarkan data di lapangan penyalahgunaan narkoba dikalangan pelajar dan mahasiswa sangat rawan. Selain mensosialisasikan bahaya narkoba ke kalangan pelajar dan mahasiswa, BNNP DIY juga membentuk kader anti narkoba dikalangan pelajar dan mahasiswa, tujuan adalah selain mahasiswa sadar serta imun akan bahaya narkoba, mereka juga dapat membantu mensosialisasikan bahaya narakoba dilingkungannya masing-masing.

Pelaksanaan kegiatan sosialisasi pencegahan narkoba untuk sasaran “ menjadikan pelajar dan mahasiswa memiliki pola pikir, sikap, dan terampil menolak menyalahgunakan narkoba ataupun mengedarkan narkoba. Melalui kegiatan sosialisasi pencegahan narkoba mencapai hasil out put rata-rata sebesar $100 \%$. Capaian dari dua wahana tersebut adalah 87 orang, yaitu peserta yang menghadiri sosialisasi tersebut semula direncanakan sejumlah 87 orang terealisasi 870 orang.

Kegiatan sosialisasi pencegahan narkoba dilakukan dengan cara mendatangi peserta di sekolah ataupun di perguruan tinggi, di sisi lain yang mendorong banyaknya peserta sosialisasi adalah antusiasnya para pimpinan sekolah, atau pimpinan perguruan tinggi untuk melibatkan siswa atau mahasiswanya di dalam sosialisasi pencegahan narkoba. 
Pada kegiatan sosialisasi pencegahan narkoba yang dilakukan oleh kasi pencegahan BNNP DIY menggunakan metode Focus Group Discussion (FGD) dengan melibatkan dari berbagai instansi terkait seperti Dinas Kesehatan, Dinas Sosial, Dinas Pendidikan Pemuda dan Olahraga (Dikpora), Polda DIY, dan juga melibatkan LSM yang peduli terhadap pencegahan narkoba. Dengan demikian antusias para peserta yang ditujukan dengan banyaknya pertanyaan yang disampaikan peserta yang ditunjukan dengan banyaknya pertanyaan yang disampaikan peserta dapat dijelaskan oleh para narasumber secara lengkap ditinjau dari berbagai segi.

\section{4.b.Sosialisasi Pencegahan Narkoba Terhadap Pekerja}

Sasaran pekerja terdiri dari pekerja di lingkunagan swasta dan lingkungan pemerintah. Hasil analisa di lapangan menunjukan bahwa tingginya penyalahgunaan narkoba di lingkungan pekerja diawali dari coba-coba ketika mereka berada di sekolah atau pun kuliah. Mereka droop out atau telah berhasil studinya, dan kemudian mereka bekerja pada umumnya di lingkungan swasta atau pun wira swasta. Dari analisas tersebut ternyata sumbernya adalah sekolah dan kampus, oleh karena itu sasaram pekerja dalam hal ini diprioritaskan pada pekerja swasta dan negeri yang berada di lingkungan sekolahan.

Sosialisasi kepada para pekerja ini materinya berbeda dengan sosialisasi terhadap para pelajar, namun tetap menggunakan metode Focus Group Discussion (FGD). Materi dititikberatkan pada:

1. Pemahaman peraturan-perundangan yang ada termasuk perda DIY terkait dengan narkoba

2. Apa yang harus dilakukan bila di lingkungannya didapati ada anak/ orang yang diduga menyalahgunakan dan mengedarkan narkoba

3. Apa yang harus dilakukan apabila mendapati pengedar di lingkungannya.
4. Semua materi lebih ditekankan pada apa yang harus dilakukan pekerja untuk membebaskan lingkungannya dari bahaya penyalahgunaan narkoba.

"Terkait dengan pencegahan narkoba, BNNP $D I Y$ selain menyasar kalangan pelajar dan mahasiswa, kita juga melakukannya dengan menyasar para pekerja, nah jadi para pekerja akan diberikan materi-materi tentang bahaya narkoba, kita juga mengajak para pekerja untuk membentuk relawan anti narkoba. Sehingga dengan begitu kita dapat bekerjasama untuk mencegah narkoba”(BW)

Selain memberikan materi-materi tentang bahaya narkoba, BNNP DIY juga turut mengajak para kelompok pekerja untuk membentuk relawan anti narkoba. Hal ini dinilai penulis sangat bagus untuk mencegah narkoba.

\section{4.c.Sosialisasi Pencegahan Narkoba Terhadap Kelompok Masyarakat}

Pencegahan narkoba terhadap masyarakat umum menjadi sasaran yang perlu diimplementasikan. Sebab mayarakat terlihat kompleks dan heterogen ini dapat membantu mensosialisasikan permasalahan narkoba. Selain itu dengan melibatkan kelompok masyarakat dapat menciptakan serta dapat membentuk masyarakat yang memiliki pola pikir, sikap, dan ketrampilan untuk turut mensosialisasikan bahaya narkoba secara mandiri.

Kalau pencegahan narkoba ke kelompok masyarakat hampir sama dengan dengan pelajar dan mahasiswa.Tetapi kalau masyarakat kan lebih kompleks dan heterogen dalam artian banyak organisasi- organisasi masa sesuai dengan karakter budaya masing-masing, ada yang kelompok pertanian, kelompok seni, nah ini tentunya kita kelompokan masing-masing. Nah pada kelompok masyarakat ini kita juga akan membentuk satgas, tetapi masyarakat juga ada lingkungan wilayah seperti, RT, RW ada juga karang taruna, sehingga karang turuan juga kita harapkan juga proaktif yang kita jadikan satgas juga atau istilah terbaru relawan anti narkoba.(BW)

BNNP DIY punya banyak cara dalam hal meningkatkan pengetahuan dan pemahamn akan permasalahan narkoba seperti dengan melibatkan atau 
mensosialisasikan narkoba ke kelompok masyarakat, sehingga masyarat turut berperan dalam pencegahan narkoba.

\section{4.d.Diseminasi Informasi Pencegahan Narkoba Melalui Seni Budaya}

Diseminasi informasi pencegahan narkoba mealului karya seni budaya/pementasan seni budaya dilaksanakan /1000 orang. Pementasan seni budaya merupakan salah satu wahana diseminasi informasi pencegahan narkoba yang dilaksanakan untuk memberikan informasi mengenai bahaya penyalahgunaan narkoba kepada masyarakat dari berbagai kalangan mulai dari pelajar, pekerja, hingga masyarakat umum.

Testimonial dari keluarga pecandu merupakan pelajaran berharga agar keluarga terutama orang tua dapat menjaga anakanaknya dengan baik, dan jika anaknya terjerumus di lubang hitam narkoba diharapkan orang tua tidak meninggalkan mereka. Selain testimonial, mereka juga memberikan tips apa saja yang perlu diwaspadai oleh orang tua agar mampu melakukan deteksi dini adanya penyalahgunaan narkoba yang dilakukan oleh anggota keluarga, terutama anak. Di acara ini juga dipasang umbul-umbul dan spanduk anti narkoba yang mengelilingi lapangan tempat terlaksanya kegiatan.

"Jadi kita ini menyesuaikan dengan budaya lokal, jadi kalau kita memberikan sosialisasisosialisasi supaya bisa membantu kan disesuaikan dengan budaya -budaya lokal. Nah kita tahu bahwa Jogja ini seni merupakan suatu buday sehingga kita bisa masuk sosialisasi narkoba dengan cara pentas seni (BW).

Menurut penulis seni budaya yang dimanfaatkan BNNP DIY sebagi media komonikasi pencegahan narkoba telah tepat, kerena Kota Yogyakarta adalah Kota yang dihiasi dengan beragam aktivitas seni budaya. Sehingga sosialisasi pencegahan narkoba yang dikemas dengan tampilantampilan seni budaya akan tersampaikan oleh masyarakat.

\section{4.e.Diseminasi Informasi Pencegahan Narkoba Melalui Pameran}

Pameran bertujuan untuk menyebarluaskan informasi mengenai bahaya penyalahgunaan narkoba kepada masyarakat Kota Yogyakarta dan sekitarnya. Pameran merupakan satu cara yang dilakukan oleh Badan Narkotika Nasional untuk mensosialisasikan narkoba terhadap Pengunjung akan bahaya narkoba.

Setiap tahun ada 2 (dua) momen yang pertama sekaten, yang kedua pamerana pembangunan. Dua momen ini merupakan kesempatan yang bisa kita manfaatkan untuk tempat diseminasi informasi atau tempat membangun penyuluhanpenyuluhan lewat standnya -standanya sehingga kunjugan-kunjungan masyarakat ketika kumpul di sekatenan, pameran pembangunan, nah ini membuat masyarakat mendapat informasi tentang masalah narkoba. Sehingga mereka akan tahu dan tertarik oh ternyata narkoba itu seperti, apa yang kita harus kita lakukan”(BW)

Pencegahan narkoba oleh Badan Narkotika Nasional Provinsi DIY dilakukan dengan cara melalui pameran. Sebab momentum pameran dapat dapat dimanfaatkan untuk menkomunikasikan bahaya narkoba terhadap pengunjung pameran. Melalui pameran ini para pengujung pameran dapat mengetahui informasi seputar narkoba.

\section{4.f.Diseminasi Informasi Pencegahan Narkoba Melalui Media Elektoronik}

Diseminasi informasi pencegahan narkoba dengan metode dialog interaktif di televisi lokal dan dialog interaktif di radio lokal. Dialog interaktif dilaksanakan dalam rangka memberikan informasi P4GN kepada masyarakat DIY dari narasumber terkait secara langsung, sehingga diharapkan informasi yang diterima lebih akurat dapat dipertanggungjawabkan.

\section{4.f.1.Dialog Interaktif Televisi Lokal}

Diseminasi informasi Pencegahan narkoba di televisi lokal dilaksanakan sebanyaka 4 (empat) kali tayang untuk menyebarluaskan informasi mengenai bahaya penyalahgunaan narkoba kepada masyarakat umum sehingga informasi yang diterima lengkap dan dari narasumber secara langsung. 
Tema setiap dialognya berbeda, antara lain Dekriminalisasi dan Depenalisasi Pengguna Narkoba, penyalahgunaan narkoba harus dicegah dan direhabilitasi, pecandupecandu dan bagaimana cara menghadapinya, pencegahan dini berbasis keluarga, proses rehabilitasi sosial bagi pecandu narkoba, dan peran mahasiswa dalam P4GN. Selama kegiatan berlangsung dibuka line interaktif dimana masyarakat yang menyaksikan dapat menyampaikan pertanyaan ataupun tanggapan melalui telpon dan sms langsung.

Melalui TV lokal ini yang kita lakukan adalah himbauan kepada masyarakat untuk hati-hati terhadap bahaya narkoba bagaiman memperhatikan anak-anaknya terhadapa bahaya narkoba jadi(Wawancara pada tanggal 21/05/2018) Ini cara kita untuk melakukan pencegahan narkoba dengan menggunakan media elektronik. Sebab televisi merupakan suatu media yang luar biasa yang cukup digemari oleh masyarakat(BW)

BNNP DIY adalah dengan memanfaatkan media elektronik yakni melalui televisi lokal. Sosialisasi pencegahan narkoba melalui TV lokal dinilai peneliti sangat tepat. Kerena televisi ini telah menjadi sumber pemberi informasi kedapa masyarakat paling besar.

\section{4.f.2.Dialog Interaktif Radio Lokal}

Dialog interaktif di radio lokal dilaksanakan sebanyak 4 kali tayang. Tema yang diangkat dalam dialog interaktif di radio yaitu sinergitas pelaksanaan program P4GN dan peran orang tua dalam pelaksanaan P4GN. Sementara tema yang diangkat dalam dialog interaktif radio Sasando FM, yaitu peran kelompok masyarakat dalam mencegah narkoba.

Selama kegiatan berlangsung pertanyaan dan tanggapan disampaikan baik melului telpon dan sms, antusias masyarakat terhadap P4GN juga terlihat dengan banyaknya permintaan dari masyarakat agar BNNP DIY melakukan siaran lebih sering lagi.

Pencegahan narkoba yang kita lakukan dengan menggunakan Radio ini dengan tujuan menghimbau kepada masyarakat tentang bahaya narkoba, agar masyarakat ini lebih berhati-hati dan waspada akan bahaya narkoba(BW)

Pencegahan narkoba oleh BNNP DIY dilakukan dengan menggunakan media elektronik seperti TV lokal dan radio lokal. Media elektronik merupakan suatu alat yang dapat membantu kasi pencegahan Badan Narkotika Nasional Provinsi DIY untuk dapat memberikana informasi-informasi seputar narkoba. Sehingga kawaspadaan masyarakat akan ancaman narkoba bisa terjaga.

\section{4.f.3.Diseminasi Informasi Pencegahan Narkoba Melalui Media Cetak}

Diseminasi informasi pencegahan melalui media cetak dilakasanakan dengan menulis buku, menulis artikel/opini pada koran, majalah, tentang Pencegahan narkoba, atau pun permberantasan dan penyalahgunaan narkoba dan peredaran gelapa narkoba. Menyebarluaskan informasi tentang narkoba, dan bahayanya melalui media cetak akan sangat membantu masayarakat untuk dapat meningkatakan pengetahuan dan pemahaman akan bahaya narkoba.

Media cetak mempunyai pengaruh sebagai seumber pemberi informasi kepada masyarakat. Koran begitu mudah dan murah untuk diperoleh oleh masyarakat. Selain itu koran juga telah menjadi media langganan masyarakat untuk mengakses berita-berita ter-updatedan aktual.

Untuk melakukan pencegahan narkoba selain memanfaatkan televisi lokal dan radio kita juga menggunakan media cetak. Pada media cetak ini yang kita lakukan adalah dengan menulis buku, atau menulis opini pada koran ataupun majalah tentang bahaya narkoba. Sehingga masyarakat dengan mudah mengakses informasi tentang bahaya narkoba itu sendiri (SY).

Media cetak juga merupaka media yang digunakan BNNP DIY untuk melakukan pencegahan terhadap narkoba. Karena media cetak seperti koran misalnya, sudah menjadi laganan sumber pemberi informasi bagi masyarakat.

\section{4.f.4.Diseminasi Informasi Pencegahan Narkoba Melalui Internet}


Desiminasi informasi pencegahan narkoba melalui internet dengan cara menyediakan website/situs. Badan Narkotika Nasional BNNP DIY telah memiliki situs internet dengan alamat www. bnnp-diy.com. Situs yang BNNP DIY menyediakan beragam informasi yang disusaikan dengan masing-masing bidang internal BNNP DIY. Infomasi yang dapat diaksses melalui situs ini adalah tentang pencegahan narkoba, pemberantasan narkoba, dan rehabilitasi pengguna narkoba. Situs ini sangat mudah untuk diakses oleh semua kompenen masyarakat baik pelajar, mahasiswa, pekerja/swasta maupun pemerintah.

internet ini juga merupakan media yang kita gunakan untuk bersosialisasi dengan masyarakat tentang narkoba yang berbasis media sosial (medos). Sekarang ini media sosial telah menjadi sarana komonikasi yang banyak digemari oleh masyarakat. Nah untuk itu kita manfaatkan media sosial ini sebagai sarana untuk mengkomuniasikan narkoba kepada masyarakat. Media sosial yang kita gunakan seperti facebook, twiter, Instagram, Website. Pada medsos yang gunakan ini diharapkan masyarakat dapat mengjungi utuk dapat mengakses informasi narakoba yang telah kita sebar ke media sosial tersebut (SY)

Melalui internet BNNP DIY juga membuka layanan media sosial melalui facebook, twitter, dan instagram. Jumlah pengikut facebook 1.126 orang, jumlah followers instagram 2.216 orang, dan jumlah follower twitter 828 orang.

\section{4.f.5.Diseminasi Informasi Pencegahan Narkoba Melaui Media Luar Ruang}

Dalam melakukan pencegahan narkoba, Badan Narkotika Nasioanl juga menggunakan media luar ruang. Media luar seperi spanduk, stikcer, dll.

Diseminasi informasi tentang pencegahan narkoba melaui media luar ruang dilaksanakan dalam bentuk pembuatan dan pemasangan spanduk/ standing banner dan penyebaran sticker. Tujuannya adalah menyebarluaskan informasi tentang narkoba danpaknya.(BW)

Dengan pemasangan sapanduk ataupun dengan penyebaran sticker yang berkonten pesan -pesan anti narkoba merupakan cara yang dilakukan oleh kasi pencegahan Badan Narkotika Nasional Provinsi DIY dalam menjalangkan tugasnya untuk memberikan penyuluhan-penyuluhan tentang pencegahan narkoba.

Diseminasi informasi yang dilakukan oleh kasi pencegahan Badan Narkotika Nasional Provinsi (BNNP) DIY terkait dengan pencegahan narkoba di Kota Yogyakarta telah dilakukan. Kegiatan diseminasi informasi pencegahan narkoba yang dilakukan oleh bidang pencegahan BNNP DIY metodenya pun beragam. Pertama, bisa dengan tatap muka seperti; Focus Group Discussion(FGD) ke kalangan pelajar, mahasiswa, kelompok masyarakat, pekerja/swasta, dan pemerintah. Kedua, melalui pameran, pentas seni budaya, misalnya kampanye anti narkoba. Kemudian yang ketiga, media yang digunakan untuk menyebarluaskan informasi pencegahan narkoba yakni; media elektronik, media cetak, internet, dan media sosial. Keempat diseminasi informasi pencegahan narkoba melalui media luar ruang, bentuknya adalah pembuatan dan pemasangan banner / di jalan, pembuatan dan penyeberan sticker dll

\section{Program Advokasi}

Advokasi merupakan program Badan Narkotika Nasional (BNN) untuk memfasilitasi instansi pemerintah dan swasta untuk menciptakan lingkungan bebas narkoba di lembaganya. Tujuan adanya advokasi adalah mendorong lembagalembaga di pemerintah dan swasta untuk membuat kebijakan atau regulasi, membuat kegiatan dan membentuk relawan yang mengarah kepada pencegahan dan pemberantasan penyalahgunaan dan peredaran gelap narkoba. (P4GN).

" Advokasi itu cenderung lebih ke sosialisasi kebijakan BNN, sasrannya instansi pemerintah dan swasta. Tujuannya untuk melakukan senergitas, biar yang melakukan P4GN itu sekata dan sama" "Kalau advokasi lebih ke instansi pemerintah dan swasta, kita mendorong mereka membuat kebijakan atau regulasi yang mengarah kepada pencegahan narkoba atau pemberantasan, penyalahgunaan dan peredaran gelap narkoba" (BW) 
Advokasi merupakan upaya Badan Narkotika Nasional (BNN) dalam mendorong instansi pemerintah maupun swasta untuk membuat kebijakan atau regulasi, mengadakan kegiatan dan membentuk relawan anti narkoba yang mengarah ke pencegahan narkoba atau pun pemberantasan dan peredaran gelap narkoba di lingkungan instansinya. Adovokasi dilakukan dengan cara kegiatan sosialisasi dan Focus Group Discussion(FGD) untuk menyepakati bagaimana instansi pemerintah atau swasta dapat menerapkan Pencegahan narkoba di lingkungan instansinya.

\section{5.a.Advokasi Pencegahan Narkoba Pada Instansi Pemerintah}

Advokasi tentang pencegahan narkoba merupakan bentuk komunikasi yang dilaksanakan untuk mendukung pelaksanaan program pencegahan narkoba. Instansi pemerintah yang diadvokasi diprioritaskan bagi para pendidik atau guru, akademisi hukum dan praktisi hukum. Hal ini diharapkan agar guru dapat menyebarluaskan informasi sekaligus dapat membuat program pencegahan narkoba di sekolah atau di kampus sesuai dengan semangat penyalamatan korban penyalahgunaan narkoba dan pecandu yang berasal dari kalangan pelajar dan mahasiswa. Sedangkan dosen dan praktisi hukum diharapkan dapat memberikan masukan terhadap program dekriminalisasi dan depenalisasi bagi para program atau pecandu narkoba.

Ya ini kan suatu advokasi itu bagaimana mempengaruhi suatu organisasi supaya ikut terlibat. Sehingga yang dibutuhkan di instansi pemerintah adalah pimpinannya jadi pimpinannya kita beritahukan ini loh bahaya narkoba, ini lo dampak sosial narkoba. Kadang anak buah kita pas waktu itu kadang-kadang terkena rayuan masalah narkoba, nah ini agar pimpinan ikut memperhatikan anak buahnya jangan sampe terlibat narkoba,sehingga tiadak mempengaruhi kinerja. Sehiangga kita harapakan dengan adanya advokasi pimpinan suatu instansi itu bisa membuta regulasi, mampu menyediakan anggaran sendiri, misalnya tes urine, atau membuat poster-poster anti narkoab.(BW)

Advokasi pencegahan narkoba bagi instansi pemerintah juga dilaksanakan dengan melaksanakan Focus Group Discussion (FGD) tentang deskriminalisasi dan depenalisasi bagi pengguna, dilaksanakan 1 kali/30 orang. Focus Group Discussion (FGD) tentang deskriminalisasi dan depenalisasi bagi pengguna dilaksanakan untuk mendapatkan masukan dan perspektif dari bidang hukum mengenai kebijakan deskriminalisasi dan depenalisasi bagi pecandu/penyalahguna narkoba.

\section{5.b.Advokasi Pencegahan Narkoba Pada Instansi Swasta}

Advokasi tentang pencegahan narkoba di lingkungan instansi swasta dilaksanakan 1 kali dengan jumlah peserta 30 orang. Advokasi tentang pencegahan narkoba di lingkungan instansi swasta dilaksanakan untuk memberikan pencerahan dan pemberdayaan pada stakeholder di lingkungan kerja dalam mengimplementasikan kegiatan pencegahan narkoba di lingkungan kerja masing-masing dan mendukung program kerja advokasi.

Hampir sama advokasi pada instansi pemerintah maupun instasi swasta. Jadi pimpianan suatu perusahaan kita ajak untuk ikut terlibat. Seperti membauat regulasi, menyediakan anggaran sendiri terkait kegiatan pencegahan narkoba, ya minimal kita harapakan dari pimpinan instasi swasta paling tidak pemasangan poster-poster ayang berisi tentang pesan anti narkoba. (BW)

Kegiatan ini membahas tentang kebijakan yang tercantum dalam UndangUndang maupun Peraturan Daerah dan standar program pencegahan sesuai standar Unit Nation of Drug and Crime . Penerapan program pencegahan narkoba di institusi swasat misalnya instansi pendidikan swasta. Untuk menekankan pentingnya life skills tarning yang diberikan pada pelajar untuk menumbuhkan kesadaran untuk selalu menghindari penyalahgunaan narkoba.

Hasil pelaksanaan kegiatan advokasi tentang pencegahan narkoba di lingkungan institusi pendidikan swasta antara lain: 
1. Program pencegahan narkoba di sekolah: adanya kegiatan peer education dan peer counselor; kegiatan bimbingan kelompok atau mentoring; memfasilitasi kegiatan ekstrakurikuler sehingga anak memiliki penyaluran kegiatan yang positif; mengadakan ESQ, sosialisasi anti narkoba di sekolah.

2. Program pencegahan narkoba dari lingkungan keluarga: manajemen waktu yang diterapkan seluruh anggota keluarga; menumbuhkan jati diri anak dengan motivasi; pengamatan orang tua terhadap perubahan yang terjadi pada anak; proteksi terhadap informasi maupun teknologi yang memberi dampak negatif pada anak, kontrol rutin media sosial.

5.c.Advokasi Pembentukan Kader Anti Penyuluh Narkoba di Lingkungan Pelajar dan Mahasiswa.

5.c.1.Pembentukan Kader Anti Penyuluh Narkoba di Lingkungan Pelajar .

Pembentukan kader anti penyuluh narkoba dilaksanakan 6 kali/240 orang. Pembentukan kader anti penyuluh narkoba dilingkungan pelajar dilaksanakan dalam rangka meningkatkan pemahaman dan kesadaran pelajar terhadap penyalahgunaan dan peredaran gelap narkoba di lingkungannya dengan cara menjadikan pelajar sebagai kader penyuluh anti narkoba yang memiliki ketrampilan menolak penyalahgunaan dan peredaran gelap narkoba dan mesosialisasikan kepada orang lain, minimal teman dan keluarga terdekatnya.

Kader/satgas yang telah dibentuk dijadikan perpanjangan tangan BNN agar dapat membantu BNN untuk menyebarluaskan bahaya narkoba kepada masyarakat luas.

"Membuat kader penyuluh anti narkoba supaya mereka bisa bergerak sendiri. Bagaimana mereka bisa bergerak menjadi perpanjangan tangan kita,bisa mengaplikasi gerakan pencegahan atau pemberantasana penyalahgunaan dan peredaran gelap narkoba (P4GN) di lingkungan mereka masing-masing.
Jadi stimulus suapaya mereka bisa bergerak sendiri, dan mandiri”.(BW)

Dalam melakukan pembentukan kader, ada kegiatan dan pelatihan yang dilaksanakan oleh calon kader. Pelatihan yang diberikan oleh kasi pencegahan BNNP DIY meliputi Traning of Trainer (TOT) supaya mereka bisa menjadi penggiat anti narkoba dalam melaksanakannya di lingkungan mereka.

Pembentukan kader penyuluh anti narkoba di kalangan pelajar diawali dengan mengikuti TOT dan pelatihan-pelatihan. Pelatihan yang diberikan meliputi kemampuan berbicara, dan pengetahuan mengenai adiksi/obat-obatan yang masuk kategori narkoba, rehabilitasi dan dasar hukum narkoba. Maka dengan begitu pencegahan narkoba yang dilakukan oleh BNNP DIY sangat bagus.

\section{5.c.2.Pembentukan Kader Penyuluh Anti Narkoba di Lingkungan Mahasiswa}

Pembentukan kader penyuluh anti narkoba di kalangan mahasiswa dilaksanakan 6 kali/240 orang. Pembentukan kader penyuluh anti narkoba di kalangan mahasiswa dilaksanakan dalam rangka meningkatkan pemahaman dan kesadaran mahasiswa terhadap penyalahgunaan dan peredaran gelap narkoba di lingkungannya dengan cara menjadikan sebagai kader penyuluh anti narkoba yang memiliki ketrampilan menolak penyalahgunaan dan peredaran gelap narkoba

"Membuat kader penyuluh anti narkoba di kalangan mahasiswa supaya mereka bisa bergerak sendiri. Bagaimana mereka bisa bergerak menjadi perpanjangan tangan kita,bisa mengaplikasi gerakan pencegahan ataupemberantasana penyalahgunaan dan peredaran gelap narkoba (P4GN) di lingkungan mereka masing-masing. Jadi stimulus suapaya mereka bisa bergerak sendiri, dan mandiri."Pembentukan kader penyuluh anti narkoba di kalangan mahasiswa ini tujuan adalah menjadikan mahasiswa tersebut memiliki pengetahuan dan kesadaran untuk imun terhadap narkoba dan bahayanya. Selain itu mahasiswa itu dapat mensosialisasikan narkoba ke teman-temanya, keluarga mau orang di sekitar lingkungannya”(BW). 
Pembentukan kader penyuluh anti narkoba di lingkungan mahasiswa merupakan suatu kerjasama dengan melibatakn instansi pendidikan atau sebagai perpanjangan tangan dari BNNP DIY untuk mesosialisasikan narkoba serta bahaya yang menyertainya. Pada kader penyuluh anti narkob akan dilatih untuk dibekali akan pengetahuan tentang pencegahan narkoba

\section{5.c.3.Pembentukan Kader Penyuluh Anti Narkoba di Lingkungan Kelompok Masyarakat.}

Pembentukan kader penyuluh anti narkoba di lingkungan masyarakat dilaksanakan 5 kali/200 orang. Pembentukan kader penyuluh anti narkoba di lingkungan kelompok masyarakat dilaksanakan dalam rangka meningkatkan pemahaman dan kesdaran anggota kelompok masyarakat terhadap penyalahgunaan narkoba dan peredaran gelap narkoba di lingkungannya, dengan cara menanamkan kesadaran diri untuk menjadi kader penyuluh anti narkoba yang memiliki ketrampilan menolak penyalahgunaan dan peredaran gelap narkoba, terutama di lingkungannya.

Kegiatan pembentukan kader penyuluh anti narkoba di lingkungan masyarakat dilaksanakan dengan penyampaian materi dari narusumber dan dilanjutkan dengan diskusi kelompok dengan metode Focus Group Discussion (FGD). Adapun materi narasumber yang disampaikan, antara lain:

a. Pengetahuan dasar tentang narkoba dan permasalahan yang menyertainya;

b. Pentingnya rehabilitasi untuk penyalahguna narkoba;

c. Teknik Public Speaking sebagai bekal menjadi penyuluh;

d. Memotivasi untuk menjadi kader dan konselor di lingkungannya;

e. Pelaksanaan teknis tes urine untuk screening narkoba;

"Pembentukan kader penyuluh anti narkob pada kelompok masyarakar itu dilakukan 5 kali dengan target 200 orang. Pembentuk kader ini dalam rangka memberikan pemahaman dan kesadaran anggota kelompok masyarakat terhadap bahaya dari narkoba itu sendiri. Serta diharapkan keder dapat menjadi penyuluh untuk menyebaluaskan pencegahan, penyalahgunaan maupun peredaran gelap narkoba.(SY)

Kader tersebut akan dapat membantu BNN untuk turut berperan aktif dalam menyebarluaskan informasi terkait dengan pencegahan, pemberantasan maupun peredaran gelap narkoba. Keberadaan kader penyuluh ini diharapkan dapat menciptakan lingkungannya dari ancaman narkoba serta dapat mengajak teman-temannya atau keluarga terdekat untuk ikut membentengi diri dari narkoba.

Berdasarkan uraian peneliti tentang capaian pencegahan narkoba yang dilakukan oleh Badan Narkotika Nasional Provinsi (BNNP) DIY terlihat berhasil, dan 100\% memenuhi target. Namun keberhasilan capain yang dilakukan oleh Badan Narkotika Nasional belum mampu menekan angka prevalensi penyalahgunaan narkoba di Kota Yogaykarta. Hal ini dapat diketahui dari hasil survei yang dilakukan oleh Badan Narkotika Nasional (BNN) dan Universitas Indonesia pada akhir tahun 2016, yang mengatakan bahwa angka prevalensi penyalahgunaan narkoba di Kota Yogyakarta tertinggi. Hal ini tentu membuat kita bertanya-tanya kenapa angka prevalensi penyalahgunaan narkoba begitu rawan di Kota Yogyakarta. Padahal sudah ada top down pencegahan narkoba dari BNN .

"Wajar kalau angka prevalensi penyalahgunaan narkoba di Yogyakarta tertinggi. Sebab kita tahu bahwa jogja ini kota dengan jumlah penduduk lebih banyak pendatang terutama pelajar dari luar jogja.Banyak kasus yang kita temui dilapangan kebanyak pendatang dari luar jogja. Nah di jogja ini banyak pengedar belum tertangkap, dan masih banyak berkeliaran, kemudian kami BNNP sendiri belum menyeluruh dalam melakukan kegiatan pencegahan narkoba ke masyarakat. Namun kami dari BNNP DIY tetap optimis untuk selalu berusaha melakukan pencegahan narkoba ke masyarakat sehingga dapat menekan angka prevalensi penyalahgunaan narkoba. (BW)

Berdasarkan hasil penelitian diatas menunjukkan capain pencegahan narkoba yang dilakukan oleh BNNP DIY belum optimal dalam menekan angka prevalensi penyalahgunaan narkoba. Hal ini disebapkan 
oleh banyak pengedar narkoba yang belum tertangkap oleh BNNP DIY, dan BNNP DIY belum menyeluruh dalam melakukan sosialisasi pencegahan narkoba ke masyarakat.

\section{Kesimpulan.}

Setelah melakukan penelitian maka peneliti berkesimpulan bahwa pencegahan narkoba yang dilakukan oleh Badan Narkotika Nasional Provinsi DIY yakni :

1. Meningkatkan Pengetahuan, Pemahaman, Kesadaran Narkoba

Dalam meningkatkan pengetahuan, pemahaman narkoba bidang pencegahan BNNP DIY memiliki program kerja yakni diseminasi informasi. Diseminasi informasi tugasnya berkaitan dengan pencegahan narkoba adalah menyebarluaskan informasi -informasi terkait dengan permasalahan narkoba, bentuknya bergam bisa dengan tatap muka, misalanya Focus Group Discussion (FGD) bentuknya bisa sosialisasi, whorkshop, seminar, dan kemudian bentuk lain bisa dengan pentas seni, dan pameran, . Kemudian Sasaran dari diseminasi informasi dalam pencegahan narkoba ini menyasar seluruh komponen masyarakat, mulai dari kalangan pelajar mahasiwa, kalangan masyarakat umum, dan juga meyasar kalangan pemerintah maupun swasta. Selain menjadi sasaran pencegahan narkoba, BNNP DIY juga mengajak suluruh komponen masyarakat untuk dapat bekerja sama untuk membentuk satgas atau relawan anti narkoba.

Selain itu bidang pencegahan BNNP DIY dalam melakukan pencegahan narkoba di Kota Yogyakarta dilakukan melalui media, baik media elektronik maupun media cetak. Media elektronik seperti TV lokal dan Radio lokal, bentuk kegiatan pencegahan narkoba adalah melakukan dialog interaktif secara langsung dengan narasumber yang bisa dari BNN, dari Kepolisian Dinas pendidikan maupun Dinas Sosial. Adapun media cetak yang digunakan kasih pencegahan BNNP DIY dalam melakukan pencegahan narkoba di Kota
Yogyakarta seperti penulisan buku, menulis opini pada koran ataupun majalah yang berkontent tentang bahaya narkoba.

2. Keterlibatan Organisasi Pemerintah dan Masyarakat

Dalam upaya melakukan pencegahan terhadap narkoba, bidang pencegahan BNNP DIY memiliki program kerja yakni advokasi. Advokasi ini merupakan program pencegahan BNNP DIY turut melibatkan instansi pemerintah maupun instansi swasta untuk turut terlibat dalam pencegahan narkoba. Jadi pada kegiatan advokasi ini yang disasar adalah para peimpinan instansi baik pemerintah maupun swasta. Tugas dari para pimpinan instansi adalah semacam membuat regulasi, meyediakan anggaran untuk keperluan kegiatan pencegahan narkoba, misalnya melakukan tes urine atau minimal pesangan poster-poster yang berisi pesan pencegahan narkoba. Jadi para pimpinan instansi dan swasta ini akan ikut bertindak dalam membantu BNNP DIY dalam mengawasi lingkungan sekitarnya dari pengaruh narkoba, dan membentuk satgas-satgas anti narkoba.

Berdasarkan urian diatas menunjukan berbagai kegiatan pencegahan narkoba yang sudah dilakukan oleh Badan Narkotika Nasional Provinsi (BNNP) DIY. Tetapi pencegahan narkoba yang dilakukan oleh Badan Narkotikan Nasional Provinsi Daerah Istimewah Yogyakarta (BNNP DIY), belum optimal korelasi yang menunjukan terget capain $100 \%$ kegiatan pencegahan narkoba dari BNNP DIY dapat mempengaruhi keberhasilan dalam menekan angka prevalensi penyalahgunaan narkoba.

\section{Daftar Pustaka.}

Berry David. I982. Pokok-Pokok Pikiran Dalam Sosiologi .Jakarta: PT RajaGrafindo, hlm 100

Denzim, Norman $\mathrm{K}$ and Yvonnas $\mathrm{S}$. Lincoln. 2009 . Qualitative Research.

Yogyakarta: Pustaka Pelajar, hlm 496

Moleong, Lexy J. (2001).Metodologi Penelitian Kualitatif. Bandung: Remaja. Rosdakar 
Moh. Soehada', Buku Daras: Pengantar Metode Sosia. Yogyakarta: Pustaka Pelajar,hlm 57

N. Gross, Mason and A.W. McEachern. 1985 . Eksploration in Role Analysis (New York : Wiley), hlm 27.

Oetarai, Ida Poernamasasi, 2014" Tahun Penyalamatan Pengguna Narkoba”. Buletin Jendela Data dan Informasi

Kesehatan. Jakarta

Ritzer ,George 2013. Sosiologi Ilmu Pengetahuan Berparadigma Ganda. Jakarta: Rajawali Pers.

Saputra,Inggar 2017. Sosialisasi Nilai Panacasila Sebagai Kunci Mengatasi Masalah Narkoba di Indonesia. Jakarta

Soedjono. 2000. Segi Hukum Tentang Narkotika di Indonesia. Bandung : Karya

Sugiyono . 2013. Metode Penelitian Pendidikan (Pendekatan Kuantitatif dan Kualitatif dan R\&D) . Bandung: Alfabeta, hlm 18

- Singarimbun, Masri dan Sofian Effendi. 1989. Metode Penelitian Survey. Jakarta: LP3ES, hlm 145

Soekanto 2004. . Sosiologi Suatu Pengantar Jakarta: Rajawali,hlm 46.

Usman, Sunyoto. 2012. SOSIOLOGI: Sejarah, Teori, dan Metodelogi. Yogyakarta: Pustaka Pelajar, hlm 59

Winda Yasinta, 2013, Upaya Badan Narkotika Nasional Propinsi Daerah Istimewah Yogyakarta Dalam Penanggulangan Peredaran Gelap Narkoba Di Yogayakarta

\section{Media Online}

Fatih Mahmud, 2015. BNN DIY: Yogyakarta Menjadi Pasar Jaringan Narkoba Internasiona $\mathrm{Di}$ akses melalui http://news.liputan6.com/read/2355544/bnndiy-jadi-jaringan-narkoba-

internasional pada 27 Februari 2018

Niervana, Anendya 25/02/2018. Mengusut Pemasok Sabu 1,6 Ton di Perairan Indonesia. Di akses melalui http://news.liputan6.com pada 12 Maret 2018

Niervana, 19/02/2018. 3 Artis Ini Tersangkut Kasus Narkoba karena Laporan Warga. Di akses dari http://news.liputan6.com pada 12 Februari 2018

Oktavia, Yuni. 15/05/2013. Promotif, Preventif, Kuratif, Rehabilitatif. Diakese dari:

http://yunivia88.blogspot.co.id/2013/ 05/promotifpreventifkuratifrehabilitatif.h $\underline{\mathrm{tml}}$ Pada tanggal 14 Maret 2018.

Yanuar.H. 02 /11/ 2015. BNN DIY: Yogyakarta Jadi Pasar Jaringan Narkoba Internasional.

Diakses

dari

www.liputan6.com/news/read/2355544/bnndiy-yogyakarta-jadi-pasar- jaringannarkoba internasional.

http://yogyakarta.bnn.go.id, diakases diakses pada 11 Maret 2018.

https://yogyakarta.bps.go.id, diakses pada 12 Maret 2018. 